\title{
Protective Effects of Selected Botanical Agents on Bone
}

\author{
James Jam Jolly ${ }^{1}$, Kok-Yong Chin ${ }^{1}$ (D), Ekram Alias ${ }^{2}$, Kien Hui Chua ${ }^{3}$ and \\ Ima Nirwana Soelaiman 1,* \\ 1 Department of Pharmacology, Faculty of Medicine, Pusat Perubatan Universiti Kebangsaan Malaysia, \\ Jalan Yaacob Latif, Bandar Tun Razak, Cheras 56000, Wilayah Persekutuan Kuala Lumpur, Malaysia; \\ jamesjamjolly@yahoo.com.my (J.J.J.); chinkokyong@ppukm.ukm.edu.my (K.-Y.C.) \\ 2 Department of Biochemistry, Faculty of Medicine, Pusat Perubatan Universiti Kebangsaan Malaysia, \\ Jalan Yaacob Latif, Bandar Tun Razak, Cheras 56000, Wilayah Persekutuan Kuala Lumpur, Malaysia; \\ ekram.alias@ppukm.ukm.edu.my \\ 3 Department of Physiology, Faculty of Medicine, Pusat Perubatan Universiti Kebangsaan Malaysia, \\ Jalan Yaacob Latif, Bandar Tun Razak, Cheras 56000, Wilayah Persekutuan Kuala Lumpur, Malaysia; \\ ckienhui@gmail.com \\ * Correspondence: imasoel@ppukm.ukm.edu.my; Tel.: +603-4040-5514
}

Received: 12 April 2018; Accepted: 8 May 2018; Published: 11 May 2018

\begin{abstract}
Osteoporosis is a serious health problem affecting more than 200 million elderly people worldwide. The early symptoms of this disease are hardly detectable. It causes progressive bone loss, which ultimately renders the patients susceptible to fractures. Osteoporosis must be prevented because the associated fragility fractures result in high morbidity, mortality, and healthcare costs. Many plants used in herbal medicine contain bioactive compounds possessing skeletal protective effects. This paper explores the anti-osteoporotic properties of selected herbal plants, including their actions on osteoblasts (bone forming cells), osteoclasts (bone resorbing cells), and bone remodelling. Some of the herbal plant families included in this review are Berberidaceae, Fabaceae, Arecaceae, Labiatae, Simaroubaceaea, and Myrsinaceae. Their active constituents, mechanisms of action, and pharmaceutical applications were discussed. The literature shows that very few herbal plants have undergone human clinical trials to evaluate their pharmacological effects on bone to date. Therefore, more intensive research should be performed on these plants to validate their anti-osteoporotic properties so that they can complement the currently available conventional drugs in the battle against osteoporosis.
\end{abstract}

Keywords: bone remodelling; complementary therapies; herbal medicine; osteoblast; osteoclast

\section{Introduction}

Osteoporosis is a metabolic bone disorder resulting from an imbalance of bone remodelling, in which the rate of bone resorption is higher than the rate of bone formation [1,2]. In turn, this gives rise to low bone mass, microarchitectural deterioration, and eventually an increased risk for fragility fractures [1-3]. Osteoporosis can be classified into primary (Type I and II) and secondary osteoporosis. Primary type I osteoporosis occurs in women soon after menopause (postmenopausal osteoporosis) and in men during and after middle-age [4]. On the other hand, primary type II or senile osteoporosis is due to old age. Both sexes may develop primary type II osteoporosis over the age of 70 , whereby both trabecular and cortical bones degenerate, thus causing proximal femora, vertebrae, and radii fractures. Women have a two-fold higher risk than men to suffer from primary type II osteoporosis due to their low peak bone mass [2,4-6]. Secondary osteoporosis is due to medications or certain medical conditions, such as hypogonadism, hyperparathyroidism, or leukemia [7]. Prolonged 
use of some medications can lead to bone loss, such as oral or high-dose inhaled corticosteroids, thyroid hormone replacement, and aromatase inhibitors [7-9]. Osteoporosis is closely associated with increased mortality due to complications of osteoporotic fractures, particularly at the vertebrae and hips $[2,10,11]$.

Most current therapies for osteoporosis focus on inhibiting bone resorption and reducing bone remodelling $[12,13]$. Parathyroid hormone, and its analogue teriparatide, are the only anabolic therapies available to treat severe osteoporosis [14]. The current drug therapies have been proven to improve bone mineral density and reduce fracture risk, but prolonged use has been associated with various side effects $[15,16]$. Therefore, the search for new drugs is ongoing $[17,18]$. In addition, the prophylactic agents for osteoporosis are limited to calcium and vitamin D. Recent advancement in phytomedicine has stimulated interests to transform herbal plants into treatment for chronic diseases, like osteoporosis [2,12,19]. Some vigorously studied herbal plants have demonstrated antiosteoporotic effects in cellular and animal studies $[13,19,20]$. These include Rhizoma alismatis [21], Curculiginis rhizoma [22], Hemidesmus indicus (L). R. Br [23], Passiflora foetida [24], Cissus quadrangularis [25], and Dalbergia sissoo [26].

In this paper, selected herbal plants which have demonstrated skeletal protecting effects in scientific studies were reviewed. Their geographical origin, active chemical components, and mechanism of action were discussed. The herbal plants included in this review were tested at least in animal or cellular (cultured osteoblasts and osteoclasts) studies, and their bioactive constituents had been identified. Six plant families originating from the Asian continent were discussed, namely Berberidaceae (East Asia), Fabaceae (East Asia), Arecaceae (Southeast Asia), Labiatae (Southeast Asia), Simaroubaceaea (Southeast Asia), and Myrsinaceae (Southeast Asia).

\section{Antiosteoporotic Constituents Extracted from Natural Plants}

\subsection{The Berberidaceae Family}

Epimedium plants (a genus of flowering plants from the Berberidaceae family) are low-growing and deciduous perennial plants [27-29]. They are also known as barrenwort, fairy wings, and bishop's hat. The leaves of other species such as Epimedium brevicornum Maxim, Epimedium sagittatum Maxim, Epimedium pubescens Maxim, and Epimedium koreanum Nakai have been used traditionally to combat osteoporosis and menopause-related diseases in China [27,30-32]. These herbal medicinal plants are used throughout the ages as an antiosteoporotic agent in Chinese traditional medicine [27,30-32]. The crude extract of Epimedium flavonoids contain icariin, epimedin B, and epimedin C. These compounds have been identified as the main antiosteoporotic constituents of Epimedium plants by inhibiting bone resorption, triggering bone formation, and blocking urinary calcium excretion [27,30-32]. They have also been shown to prevent osteoporosis without causing uterine hyperplasia in the ovariectomized rat model $[20,27,30,31]$.

The Epimedium flavonoids possess estrogenic activity and improve the maturation of osteoblasts by inducing the expression of alkaline phosphatase (ALP), bone morphogenetic protein-2 (BMP-2) and core binding factor $\alpha 1(\mathrm{Cbf} \alpha 1)$. They also increase expression of osteoprotegerin (OPG) but reduce the expression of receptor activator of nuclear factor- $\mathrm{KB}$ ligand (RANKL), thereby inhibiting the formation of osteoclasts $[27,30-33]$. Several studies also showed that Epimedium flavonoids upregulated expressions of BMP or Wingless-type signalling (Wnt-signaling) pathway related regulators, like cyclin D [20,27,30,31].

Icariin has been identified as the most active flavonoid glucoside extract of Epimedium plant $[27,31]$. Icariin inhibits bone loss in the distal femur and tibia in ovariectomized rat models $[20,27,30,31]$. It is suggested that icariin activates estrogen receptor (ER) and induces ER-dependent bone activity $[20,27,30,31]$. Icariin also decreases the tartrate-resistant acid phosphate activity (TRAP) activity of osteoclasts, their size and bone resorption activity. This is achieved by lowering IL-6 and TNF- $\alpha$ expression [20,27,30,31]. Icariin can inhibit cyclooxygenase type-2 (COX-2) 
activity, expression of LPS-induced hypoxia inducible factor- $1 \alpha$ (HIF- $1 \alpha)$, and activation of the p38 and c-Jun N-terminal kinase (JNK) in osteoclasts $[20,27,30,31]$. It also inhibits osteoclasts differentiation by reducing ERK1/2 and $\mathrm{I} \kappa$-B $\alpha$ LPS-induced activation [20,27,30,31].

Ikarisoside A is a natural flavonoid extracted from Epimedium species of E. koreanum. It possesses antioxidant and anti-inflammatory properties in LPS-stimulated bone marrow-derived macrophage precursor cells and in RAW264.7 cells [20,30,31]. It also inhibits the formation of osteoclasts and bone resorption activity from these precursor cells [20,31]. Moreover, Ikarisoside A reduces the expression of osteoclastic genes, such as TRAP, matrix metalloproteinase 9 (MMP-9), cathepsin K, and receptor activator of NF-KB (RANK) $[20,30,31]$. This is achieved by suppressing the activation of the nuclear factor kappa-light-chain-enhancer of activated B cells (NF- $\mathrm{kB}$ ), JNK, and protein kinase B (Akt)-RANKL [20,30,31]. Thus, it can be concluded that Ikarisoside A has the potential to be used as a remedy to treat diseases involving rheumatoid arthritis and osteoporosis $[20,30,34]$

\subsection{The Fabaceae Family}

The soybean, scientifically known as Glycine max L. (Fabaceae), is mainly grown in Southwest Asia [27]. It is a rich source of proteins and flavonoids, such as daidzein, biochanin A, and genistein [27]. Supplementing soybean protein in the diet is effective in reducing the loss of bone mineral density in ovariectomized rats $[27,35,36]$. In animal models of bone loss, isoflavones can preserve trabecular microstructure $[27,37]$. They act by modulating gene expression of collagen type I (COL I), osteocalcin, calciotropic receptor, ALP, cytokines, and growth factors [27,38]. The phytoestrogens in soybean have been shown to exert significant effects on bone metabolism in postmenopausal women. It could be used as a dietary supplement to prevent postmenopausal osteoporosis since isoflavones can improve bone turnover markers, bone mineral density, and bone strength among postmenopausal women [27,36-38]. However, the skeletal effects of soy isoflavones supplementation in humans remain debatable because several meta-analyses reported that the effects were minimal $[39,40]$. Nevertheless, further studies are necessary to verify the magnitude of the skeletal effects of soy isoflavones in humans.

Genistein is an isoflavone exhibiting estrogenic effect on bone. It modulates B-lymphopoiesis in bone marrow and inhibits bone degradation without any estrogenic effect in the uterus [27,41]. The antiosteoporotic effects of flavonoids depend on the mixture of their estrogenic agonist-antagonist properties [27,41]. Other studies suggest that the antiosteoporotic effects may be derived from other biochemical properties of flavonoids, including enzymatic inhibition of certain protein kinases or activation of estrogen type I receptors [27]. The clinical effectiveness of the flavonoids may be dependent on their ability to produce equol, an isoflavandiol metabolized by gut microflora from daidzein [27,42]. It shows a higher estrogenic activity than the predominant flavonoids [27,42].

Herbal plants of the species Psoralea corylifolia L. (commonly known as Malay Tea, Cot Chu, or Ku Tzu locally) belongs to the family Fabaceae [27]. The fruit of this plant is used traditionally to treat bone fractures, osteomalacia, osteoporosis, and joint disorders [13,43]. The fruit extract of P. corylifolia significantly increases the serum concentration of inorganic phosphorus and induces bone calcification in rats $[27,43]$. The crude extracts of its fruit and seed, as well as two of its dominant isoflavones (corylin and bavachin), have been found to stimulate bone formation [27,43]. Extracts of P. corylifolia from different parts of the plants also contain bakuchalcone, psoralen, bakuchiol, psoralidin, bavachinin, isopsoralen, and flavones [44].

Some bioactive compounds isolated from P. corylifolia have been found to exert bone-protective effects. Bavachalcone can inhibit osteoclastogenesis by hindering the ERK and Akt signaling, as well as Chromosome-Fos (c-Fos) and nuclear factor of activated T cells c1 (NFATc1) induction during differentiation $[27,43]$. Psoralidin, bakuchiol, isobavachin, and corylin have been found to have strong antioxidant activities, whereas other compounds, such as bavachin and corylin, have been shown to stimulate osteoblastic proliferation $[13,27]$. Bakuchiol has a three-fold higher binding affinity for estrogen receptor alpha $(E R \alpha)$ than for estrogen receptor beta $(E R \beta)[13,27]$. It does not have significant uterotrophic activity, although demonstrating in vitro estrogenic activity $[27,45]$. It 
can reduce postmenopausal bone loss by increasing ALP, calcium concentrations, serum estrogen concentration, and bone mineral density [27,45]. Psoralen, a coumarin-like derivative extracted from the fruit of $P$. corylifolia L., has stimulatory effects on new bone formation $[27,46,47]$. It also modulates differentiation of osteoblasts in a dose-dependent manner in primary mouse calvariae by upregulating osteoblast-specific genes expression of osteocalcin, type I collagen, and sialoprotein [46,47]. Psoralen affects BMP signalling activation in order to promote differentiation of osteoblasts [46-48]. It stimulates BMP-2 and BMP-4 gene expression, as well as increases phospho-Smad1/5/8protein level [46-48]. This evidence suggests that psoralen is a potent anabolic agent in treating osteoporosis [46-48].

\subsection{The Arecaceae Family}

Oil palm in the palm family (Arecaceae) is mostly cultivated as a source of oil [49]. Oil palm is grown extensively in the equator region of native West and Central Africa, as well as in Asian countries including Malaysia and Indonesia [50]. The most planted species of Arecaceae Family is Elaeis guineensis (African oil palm) and other species such as Elaeis oleifera (American oil palm) and Attalea maripa (Maripa palm) are lesser known [51]. Palm oil is an edible vegetable oil derived from the mesocarp (orange-red pulp) of the oil palm fruits [49]. It is naturally reddish in colour due to the presence of high beta-carotene content [52,53].

Palm oil of Elaeis guineensis is well known to have high content of vitamin E [49]. Vitamin E is a conjoint term for tocopherol and tocotrienol isoforms which are well-known for their antioxidant and anti-inflammatory properties as well as other beneficial effects on the body $[54,55]$. Both isoforms of tocopherols and tocotrienols exist in four different forms in nature: namely; $\alpha-, \beta-, \gamma-$, and $\delta-[55,56]$. In nature, these isomers are normally present as a mixture of varying composition [57]. For example, vitamin E extracted from crude palm oil consists of around $36 \% \alpha$-tocopherol, and the rest are made up by the four tocotrienol isomers [58]. On the other hand, vitamin E from annatto extract comprises of approximately $90 \% \delta$-tocotrienol and the rest is $\gamma$-tocotrienol [59].

The anti-oxidative and anti-inflammatory properties of tocotrienol make it a suitable anti-osteoporotic agent $[60,61]$. Both oxidative stress and inflammation are known to be involved in the pathogenesis of osteoporosis [62,63]. Oxidative stress has been shown to harm osteoblasts by affecting their differentiation and survival rate [64]. Additionally, oxidative stress also enhances the signalling of osteoclasts and simultaneously promotes their differentiation [65]. Proinflammatory cytokines—such as interleukin-1, interleukin-6, and tumour necrosis factor $\alpha$-are also increased by oxidative stress, and they are also harmful to the bone [66].

A study by Hermizi et al. (2009) has shown that, both tocotrienol-rich fraction and gamma-tocotrienol supplementations were effective in retaining trabecular bone structure in nicotine-induced bone loss model [67]. Also, Aktifanus et al. (2012) and Soelaiman et al. (2012) have reported that, supplementation with tocotrienol reduced single-labelled surface and increased double-labelled surface in the ovariectomized rats $[68,69]$. In addition, ovariectomized rats supplemented with 30 and $60 \mathrm{mg} / \mathrm{kg}$ body weight of palm vitamin E had shown significantly higher bone mineral density at the femur and vertebrae as compared to the control untreated group [70]. Similar findings were reported in the testosterone deficiency, buserelin, and glucocorticoid-induced bone loss model [71-76]. Studies also have shown that palm vitamin E was able to restore bone calcium levels in the femur and vertebra of orchidectomized and ovariectomized rats [70,71].

The skeletal effects of vitamin E have been tested in many human studies but in most cases synthetic alpha-tocopherol was used (reviewed in [77,78]). The efficacy of palm vitamin E mixture rich in tocotrienol in preventing osteoporosis has not been studied so far. A similar vitamin E mixture, also rich in tocotrienol, from annatto beans has been tested by Shen et al. (2018) [79]. The results showed that tocotrienol decreased bone resorption markers and oxidative stress in post-menopausal osteopenic women after 12 weeks [79]. 


\subsection{The Labiatae Family}

A Chinese herb known as Salvia miltiorrhiza Bunge (commonly known as 'dan shen' or 'red sage root') from the family of Labiatae is traditionally used to treat diseases related to cardio-cerebral disorders $[48,80,81]$. S. miltiorrhiza has been shown pharmacologically to possess anticoagulation, blood flow improvement, anti-inflammatory, free radical scavenging, and mitochondrial protective properties $[48,81,82]$. Phytochemical studies of S. miltiorrhiza Bunge have revealed multiple groups of compounds, including tanshinones (tanshinone I, tanshinone IIA, 16-dihydrotanshinone I, cryptotanshinone) and phenolics (salvianolic acid A, protocatechuicaldehyde, and salvianolic acid B) $[27,83,84]$. Treatment with $S$. miltiorrhiza significantly prevents the decrease in trabecular bone mass and bone mineral density, reduces TRAP activity and parameters of oxidative stress, which includes malondialdehyde (MDA) and nitric oxide (NO) induced by sex hormones deficiency in rodents $[20,27,82]$. Tanshinones are reported to reduce the TRAP-positive multinucleated osteoclast formation [85]. Tanshinone IIA is proven to partially inhibit ovariectomy-induced bone loss by reducing bone turnover in vivo $[27,85,86]$. It inhibits osteoclast formation by suppressing the c-fos and NFATc1 expression induced by RANKL $[27,85,86]$.

Salvianolic acid A from S. miltiorrhiza Bunge can inhibit bone loss in rats given long-term prednisone $[20,87]$. This is achieved by regulating osteogenesis and suppressing adipogenesis in bone marrow stromal cells $[20,87]$. Similarly, Salvianolic acid B has been used to inhibit glucocorticoid-induced cancellous bone loss and suppress adipogenesis [20]. It modulates the differentiation of bone marrow stromal cell (MSC) to osteoblasts and upregulates osteoblastic activities. It decreases the differentiation of glucocorticoid-associated adipogenesis through modulating the expression of Dickkopf-1, RUNX2, peroxisome proliferator-activated receptor-gamma (PPAR- $\gamma$ ), and $\beta$-catenin in MSC [20,88].

\subsection{The Simaroubaceae Family}

Tongkat Ali, also known as Eurycoma longifolia, from the family Simaroubaceae, is a traditional herbal plant found in Malaysia $[89,90]$. The root extract of Tongkat Ali is a well-known folk remedy among the Malaysians used to enhance fertility and sexuality, and delay ageing [89]. The bioactive compounds of these plants contain quassinoid alkaloids which are believed to cure allergies, relieve fevers, reduce tumours, and treat malaria $[89,91]$. Other bioactive compounds found in this plant are tannins and high-molecular-weight glycoproteins, polysaccharides and mucopolysaccharides [89].

Eurycomalactone, eurycomanone, and eurycomanol of E. longifolia have been shown to increase testosterone level in the blood and are capable of inhibiting the sex hormone-binding globulin $[89,92,93]$. Testosterone is known to enhance bone formation and prevent osteoporosis $[89,94,95]$. Testosterone and 5- $\alpha$-dihydrotestosterone suppress RANKL and the number of colony-forming unit-macrophages, thereby reducing osteoclast numbers [96]. Consequently, the bone degradation process will be halted and bone density will be maintained [92,93]. Testosterone replacement increases bone density and mass and is an effective treatment for male osteoporosis due to hypogonadism [89,93-95,97]. However, it comes with some side effects, such as increased risk for prostate cancer, polycythemia, and cardiovascular events [98]. E. longifolia, as an androgenic compound, may act as an alternative to prevent osteoporosis associated with low testosterone level $[89,92,93]$. It has a good safety profile and convenient oral administration $[89,92,93]$.

\subsection{The Myrsinaceae Family}

The herbal plant traditionally known as Kacip Fatimah (Labisia pumila) belongs to the family Myrsinaceae $[99,100]$. Labisia pumila water extract is traditionally used by Malay women to treat menstrual irregularities and dysmenorrhoea [99,100]. It is also used to improve uterine contraction post-delivery and to promote sexual function $[99,100]$. Its water extract is also being consumed to treat diseases such as gonorrhoea, rheumatism, dysentery, and bone disorders [101]. The plant 
L. pumila is capable of inducing the production of estrogen. Post-menopausal women are prone to have osteoporosis due to decreased circulating estrogen $[100,102]$. Estrogen induces osteoclast apoptosis and inhibits osteoblast apoptosis $[99,100]$. This reduces bone degradation and increases bone formation activity $[99,100]$.

Pro-inflammatory cytokines, such as IL-1 and IL-6, are capable of influencing osteoclastogenesis by self-renewal stimulation [101]. These pro-inflammatory cytokines are inhibited by the presence of estrogen [99,101,102]. According to recent studies, L. pumila is capable of inducing the production of estrogen. Therefore, L. pumila can be regarded as an alternative to estrogen replacement therapy (ERT) $[99,101,102]$.

Also, L. pumila exerts anti-oxidant properties due to the presence of active compounds, such as ascorbic acid, anthocyanin, beta-carotene, flavonoids, and phenolic compounds [101,102]. Other active constituents of L. pumila, such as anthocyanin and phenolics, also play a role as anti-oxidant and anti-inflammatory agents $[101,102]$. These effective free radical scavengers can help to improve chronic diseases related to oxidative stress [102].

\section{Perspectives}

Several important issues should be considered when using natural herbal plants to treat osteoporosis. These issues are (i) selectivity: the mechanism of action, selective binding to sites of action and any possible resistance of the compound towards bioactive site action; (ii) therapeutic/pharmaceutical index: the benefit-to-risk ratio of the applied bioactive compound and clinical trials before being used as a standard therapy or along with standard therapy; (iii) controllability: the rate of targeted bioactive compound must be clear, reproducible and controllable; and lastly, (iv) convenience: preferably, the drug should be orally administered; therefore the liquid or tablet dosage form must be initially formulated and stabilized, making it easier to be taken orally [22].

The safety of herbal remedies should also be studied intensively. There is a widespread belief that herbals are natural and harmless. However, studies have shown that hepatotoxicity is the most frequently reported toxic effect of herbal remedies [22,100]. Therefore, precise investigation of the bioactive compounds and scientific data regarding the safety and toxicity are needed before definite clinical trials are conducted.

In addition, standardization of medical herbal plants should also be emphasized. The lack of standardization has contributed to difficulties in validating the efficacy of the plants, which is important for further study of targeted bioactive compounds. Plants that are commonly used in laboratory experiments should be investigated thoroughly in terms of their pharmacology and therapeutic effect before being tested in patients suffering from osteoporosis and other bone-related diseases.

Many natural herbal plants have the potential to be developed as anti-osteoporotic agents. However, only a fraction of these plants has been thoroughly investigated by researchers. More reliable, efficient, and rapid bioassays should be developed to examine the antiosteoporotic efficacy of these botanical extracts, as well as to identify the compounds responsible for the bone-protective effects and mechanism involved. Most anti-osteoporotic agents derived from herbal medicinal plants can be used as prophylactic rather than therapeutic agents. If no clinical trials are done, the application and development of these herbal plants will remain restricted and undiscovered. It is important to translate laboratory findings to clinical outcomes to enable drugs from natural plants to be used for human therapy.

There are some limitations pertaining to the discussion of this review. Quality assessment was not performed on the studies included in this review. Therefore, some studies quoted might be subjected to biases and errors. The readers should interpret the studies with caution. Most botanical agents cited do not have a complete safety profile, either in animal or in humans. In most animal studies, the efficacy data of these botanical agents are not complemented with safety data. Therefore, the therapeutic index of these agents remains elusive to the readers. 


\section{Conclusions}

Herbal plants are a rich source of medicinal compounds that can be used to prevent osteoporosis. Many animal and cellular studies have been conducted to demonstrate the antiosteoporotic effects of these botanical extracts and their bioactive compounds (Table 1). They modulate bone remodelling by acting directly on the bone cells or through lowering oxidative stress and inflammation or increasing sex hormone levels (Figure 1). Through enhancing bone formation and suppressing bone reabsorption, these agents can improve bone mass and reduce the risk of fragility fracture. Fracture prevention also relies on improvements in muscle strength, coordination, and cognitive function. Botanical agents may affect these bodily functions, but they are outside the scope of this review. A proper human clinical trial to validate their bone-protective effects needs to be conducted. The use of botanical compounds as an intervention for osteoporosis also faces issues of standardization, selectivity, and safety. These issues should be overcome to promote their use in preventing osteoporosis.

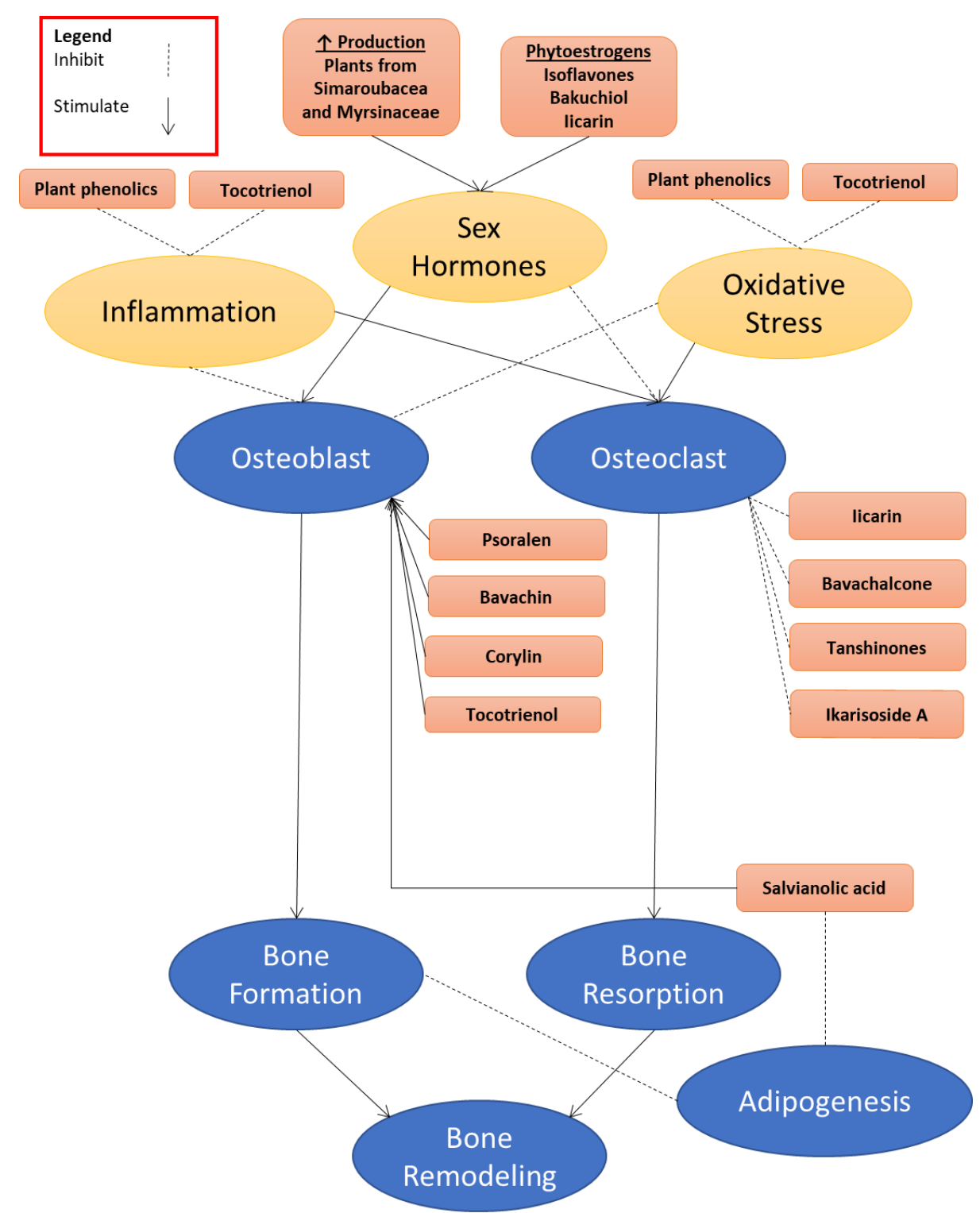

Figure 1. The role of botanical bioactive compounds in regulating bone metabolism. They may act directly on the bone cells, or through reducing inflammation and oxidative stress, or indirectly via increasing the level of sex hormones and interacting with sex hormone receptors on bone cells. 
Table 1. Summary of anti-osteoporotic properties of medicinal plants.

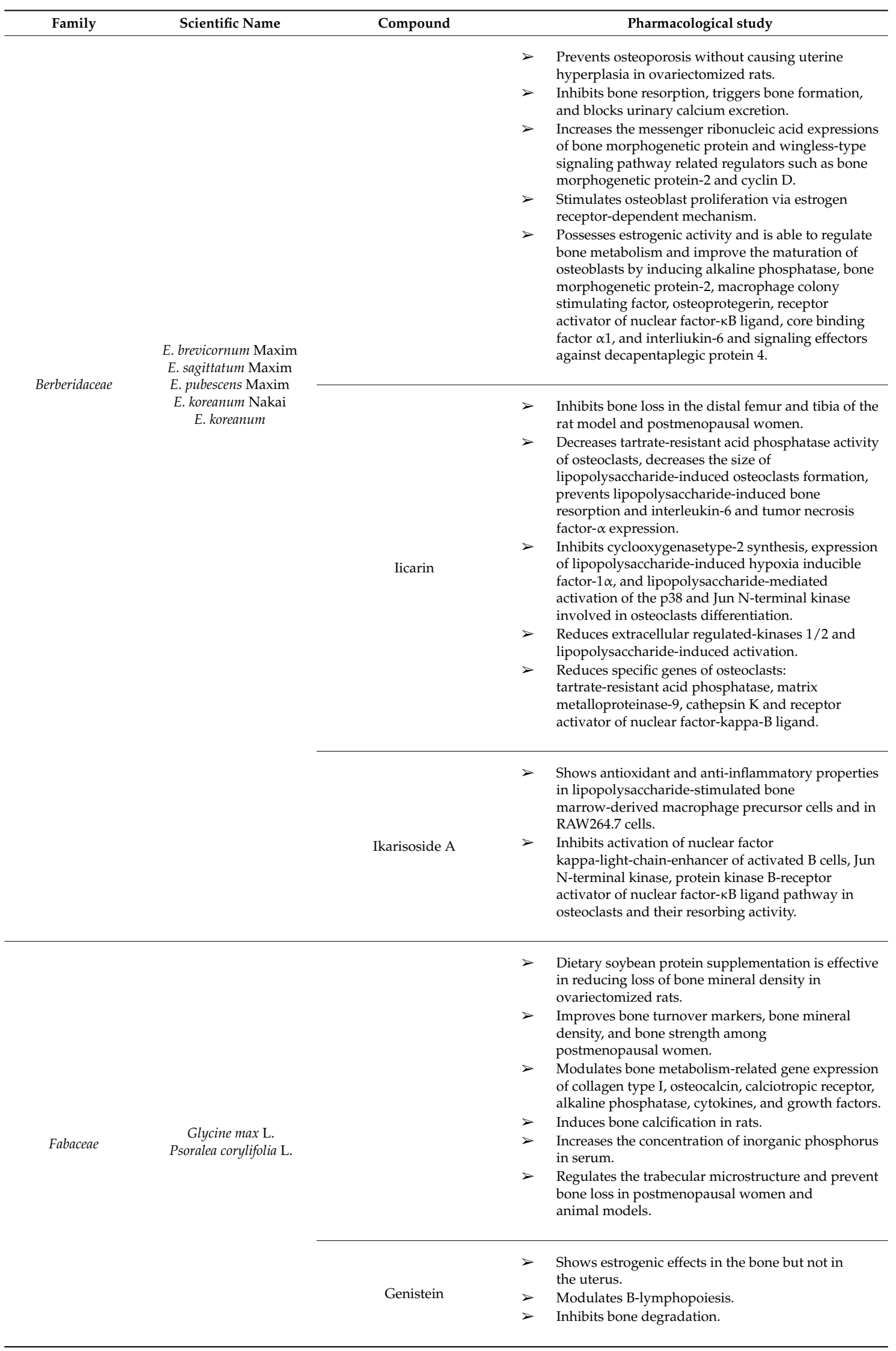


Table 1. Cont.

\begin{tabular}{|c|c|c|c|}
\hline Family & Scientific Name & Compound & Pharmacological Study \\
\hline \multirow{5}{*}{ Fabaceae } & \multirow{5}{*}{$\begin{array}{l}\text { Glycine max } \mathrm{L} . \\
\text { Psoralea corylifolia } \mathrm{L} \text {. }\end{array}$} & Bavachalcone & $\begin{array}{l}\text { Inhibits osteoclastogenesis. } \\
\text { Inhibits the extracellular regulated-kinases and } \\
\text { protein kinase B signalling and chromosome-Fos and } \\
\text { nuclear factor of activated T cells c1 induction } \\
\text { during differentiation. }\end{array}$ \\
\hline & & Psoralidin, Isobavachin & $>$ Strong antioxidant. \\
\hline & & Bavachin Corylin & $>$ Stimulates osteoblastic proliferation. \\
\hline & & Bakuchiol & $\begin{array}{l}\text { Has high binding affinity for ER } \alpha . \\
\text { Shows no significant uterotrophic activity. } \\
>\quad \text { Stimulates estrogenic activity in vitro. } \\
\text { Reduces postmenopausal bone loss by increasing } \\
\text { alkaline phosphatase, calcium concentrations, serum } \\
\text { estrogen concentration, and bone mineral density. }\end{array}$ \\
\hline & & Psoralen & $\begin{array}{l}\text { Stimulates new bone formation. } \\
>\quad \text { Stimulates differentiation of osteoblasts in a } \\
\text { dose-dependent manner in primary mouse calvariae. } \\
\text { Upregulates osteoblast-specific genes expression of } \\
\text { osteocalcin, type I collagen and sialoprotein. } \\
>\quad \begin{array}{l}\text { Stimulates bone morphogenetic protein- } 2 \text { and bone } \\
\text { morphogenetic protein-4 gene expression. }\end{array}\end{array}$ \\
\hline \multirow[t]{2}{*}{ Arecaceae } & Elaeis guineensis & Tocotrienol & $\begin{array}{l}\text { Well-known for their antioxidant, anti-oxidative } \\
\text { stress, anti-inflammatory properties and } \\
\text { anti-osteoporotic agent. } \\
\text { Suppresses the proinflammatory } \\
\text { cytokines expression. } \\
\text { Effective in retaining trabecular bone structure in the } \\
\text { nicotine-induced bone loss model. } \\
\text { Reduces of single-labelled surface and increased in } \\
\text { double-labelled surface in the ovariectomized rats. } \\
\text { Increases bone mineral density at the femur and } \\
\text { vertebrae of the rats in the testosterone deficiency } \\
\text { and the glucocorticoid bone loss model. } \\
\text { Restores bone calcium level at the femur and } \\
\text { vertebra of orchidectomized and } \\
\text { ovariectomized rats. } \\
\text { Improves biomechanical strength of the femur in } \\
\text { normal male rats. }\end{array}$ \\
\hline & \multirow{4}{*}{ Salvia miltiorrhiza Bunge } & & $\begin{aligned} & \text { In ovariectomized rats: } \\
&>\quad \text { Prevents the decrease in trabecular bone mass and } \\
& \text { bone mineral density. } \\
&>\quad \text { Reduces the tartrate-resistant acid } \\
& \text { phosphatase activity. } \\
& \quad \text { Decreases oxidative stress. }\end{aligned}$ \\
\hline \multirow[t]{3}{*}{ Labiatae } & & Tanshinones & $\begin{array}{l}\text { Reduces the tartrate-resistant acid } \\
\text { phosphatase-positive multinucleated } \\
\text { osteoclast formation }\end{array}$ \\
\hline & & Tanshinones IIA & $\begin{array}{l}\text { Partially inhibits ovariectomy-induced bone loss by } \\
\text { reducing bone turnover. }\end{array}$ \\
\hline & & Salvianolic acid A & $\begin{array}{l}\text { Inhibits bone loss in rats given } \\
\text { long-term prednisone. } \\
>\quad \text { Stimulates osteogenesis. } \\
>\quad \text { Suppresses adipogenesis in bone marrow } \\
\text { stromal cells. }\end{array}$ \\
\hline
\end{tabular}


Table 1. Cont.

\begin{tabular}{|c|c|c|c|}
\hline Family & Scientific Name & Compound & Pharmacological Study \\
\hline Labiatae & Salvia miltiorrhiza Bunge & Salvianolic acid B & $\begin{array}{l}\text { Inhibits glucocorticoid-induced cancellous bone loss. } \\
\quad \text { Suppresses adipogenesis. } \\
\text { Stimulates bone marrow stromal cell differentiation } \\
\text { to osteoblasts. } \\
\text { Upregulates osteoblastic activities. } \\
\text { Modulates the expression of messenger of } \\
\text { ribonucleic acid of dickkopf-1, runt-related } \\
\text { transcription factor 2, peroxisome } \\
\text { proliferator-activated receptor gamma, and } \\
\beta \text {-catenin in mesenchymal stem cell. }\end{array}$ \\
\hline \multirow{3}{*}{ Simaroubaceaea } & \multirow{3}{*}{ Eurycoma longifolia } & & Androgenic substance with a good safety profile. \\
\hline & & $\begin{array}{l}\text { Eurycomalactone } \\
\text { Eurycomanol }\end{array}$ & $\begin{array}{l}>\quad \text { Increases testosterone level in the blood. } \\
>\quad \text { Inhibits sex hormone-binding globulin. }\end{array}$ \\
\hline & & Eurycomanone & Increases testosterone level in the blood. \\
\hline \multirow{2}{*}{ Myrsinaceae } & \multirow{2}{*}{ Labisia pumila } & & $\begin{array}{l}>\text { Used traditionally to treat female sexual problems. } \\
>\quad \text { Stimulates the production of estrogen. } \\
>\quad \text { Stimulates the production of estrogen. }\end{array}$ \\
\hline & & $\begin{array}{l}\text { Ascorbic acid } \\
\text { Anthocyanin } \\
\text { Beta-carotene, } \\
\text { Flavonoids phenolic } \\
\text { compounds }\end{array}$ & $\begin{array}{l}\text { Anti-oxidant and free radical scavengers-effective } \\
\text { free radical scavengers in conditions, such as } \\
\text { osteoporosis and rheumatism, which are related to } \\
\text { ageing and oxidative stress. } \\
\text { Anti-inflammatory agents. }\end{array}$ \\
\hline
\end{tabular}

Author Contributions: All authors contributed equally to the writing of this manuscript.

Acknowledgments: We thank Universiti Kebangsaan Malaysia for supporting the study via grant GUP-2017-060 and GUP-2017-012.

Conflicts of Interest: The authors report no conflicts of interest in this work.

\section{Abbreviations}

ALP

BMP-2/4

M-CSF

OPG

RANKL

$\operatorname{Cbf} \alpha 1$

SMAD4

Wnt-signaling

cyclinD

OVX

ER

TRAP

LPS

IL-6/1

TNF- $\alpha$

COX-2

HIF- $1 \alpha$

p38

JNK
Alkaline phosphatase

Bone morphogenetic protein-2/4

Macrophage colony stimulating factor

Osteoprotegerin

Receptor activator of nuclear factor- $\mathrm{kB}$ ligand

Core binding factor $\alpha 1$

Signaling effectors mothers against decapentaplegic protein 4

Wingless-type signaling

Cyclin dependent

Ovariectomized

Estrogen receptor

Tartrate-resistant acid phosphatase

Lipopolysaccharides

Interleukin-6/1

Tumor necrosis factor

Cyclooxygenasetype-2

Hypoxia inducible factor- $1 \alpha$

Protein 38

Jun N-terminal kinase 


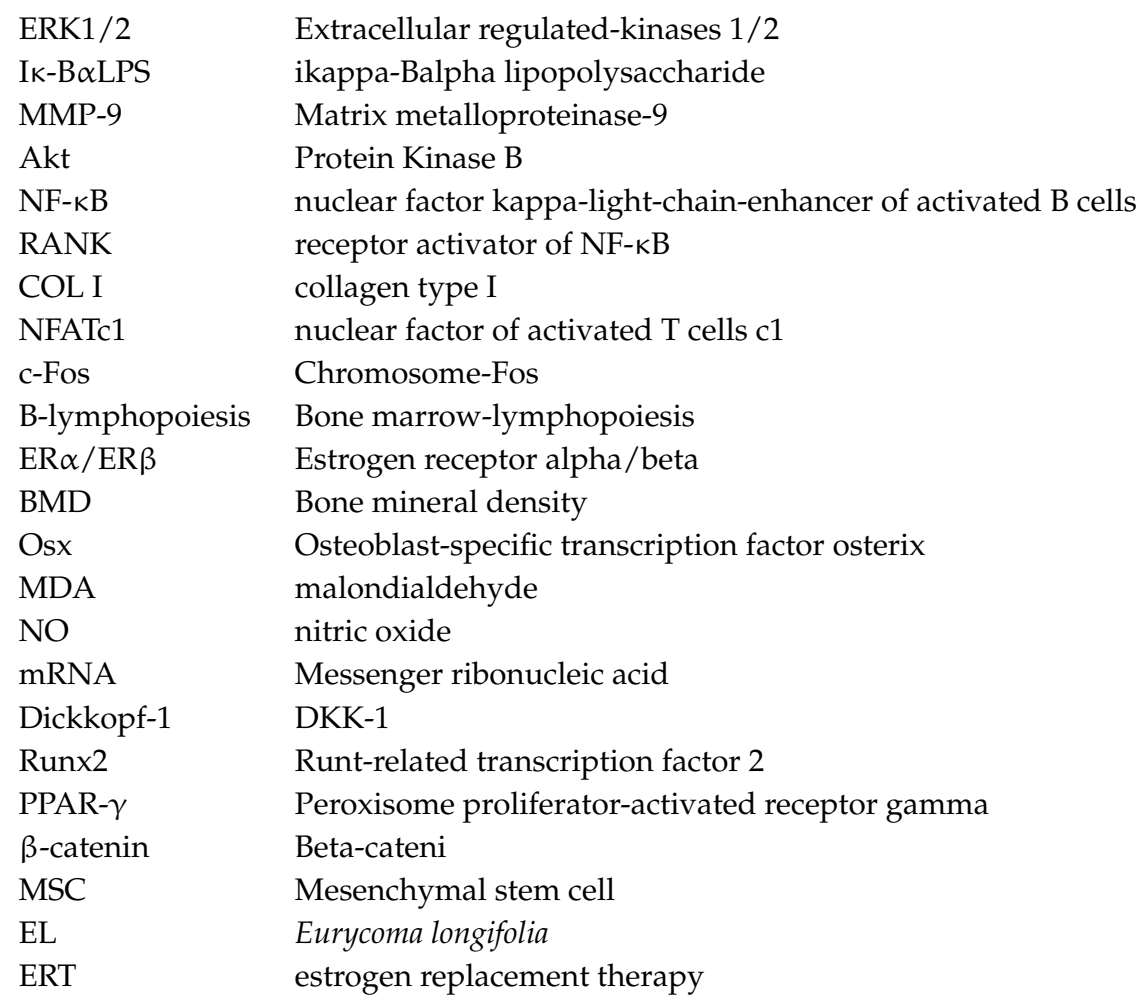

\section{References}

1. Lama, A.; Santoro, A.; Corrado, B.; Pirozzi, C.; Paciello, O.; Pagano, T.B.; Russo, S.; Calignano, A.; Mattace Raso, G.; Meli, R. Extracorporeal shock waves alone or combined with raloxifene promote bone formation and suppress resorption in ovariectomized rats. PLoS ONE 2017, 12, e0171276. [CrossRef] [PubMed]

2. Sucuoglu, H.; Koyuncu, H. Distribution of male osteoporosis patients according to age, classification, and fracture. Istanb. Med. J. 2017, 18, 13-17. [CrossRef]

3. Poole, K.E.S.; Skingle, L.; Gee, A.H.; Turmezei, T.D.; Johannesdottir, F.; Blesic, K.; Rose, C.; Vindlacheruvu, M.; Donell, S.; Vaculik, J.; et al. Focal osteoporosis defects play a key role in hip fracture. Bone 2017, 94, 124-134. [CrossRef] [PubMed]

4. Iseme, R.A.; Mcevoy, M.; Kelly, B.; Agnew, L.; Walker, F.R.; Attia, J. Is osteoporosis an autoimmune mediated disorder? Bone Rep. 2017, 121-131. [CrossRef] [PubMed]

5. $\quad$ Eastell, R.; Christiansen, C.; Grauer, A.; Kutilek, S.; Libanati, C.; McClung, M.R.; Reid, I.R.; Resch, H.; Siris, E.; Uebelhart, D. Effects of denosumab on bone turnover markers in postmenopausal osteoporosis. J. Bone Miner. Res. 2011, 26, 530-537. [CrossRef] [PubMed]

6. Szulc, P.; Delmas, P. Bone loss in elderly men: Increased endosteal bone loss and stable periosteal apposition. The prospective minos study. Osteoporos. Int. 2007, 18, 495-503. [CrossRef] [PubMed]

7. Misiorowski, W. Osteoporosis in men. Prz. Menopauzalny 2017, 16, 70-73. [CrossRef] [PubMed]

8. Moreira-Marconi, E.; Dionello, C.F.; Morel, D.S.; Sá-Caputo, D.C.; Souza-Gonçalves, C.R.; Paineiras-Domingos, L.L.; Guedes-Aguiar, E.O.; Marin, P.J.; del Pozo Cruz, B.; Bernardo-Filho, M. Could whole body vibration exercises influence the risk factors for fractures in women with osteoporosis? Osteoporos. Sarcopenia 2016, 2, 214-220. [CrossRef]

9. Rachner, T.D.; Khosla, S.; Hofbauer, L.C. Osteoporosis: Now and the future. Lancet 2011, 377, $1276-1287$. [CrossRef]

10. Orcel, P.; Funck-Brentano, T. Medical management following an osteoporotic fracture. Orthop. Traumatol. Surg. Res. 2011, 97, 860-869. [CrossRef] [PubMed]

11. Khosla, S.; Hofbauer, L.C. Osteoporosis treatment: Recent developments and ongoing challenges. Lancet Diabetes Endocrinol. 2017, 5, 898-907. [CrossRef] 
12. Wu, L.; Ling, Z.; Feng, X.; Mao, C.; Xu, Z. Herb medicines against osteoporosis: Active compounds \& relevant biological mechanisms. Curr. Top. Med. Chem. 2017, 17, 1670-1691. [PubMed]

13. Augustine, M.; Horwitz, M.J. Parathyroid hormone and parathyroid hormone-related protein analogs as therapies for osteoporosis. Curr. Osteoporos. Rep. 2013, 11, 400-406. [CrossRef] [PubMed]

14. Reginster, J.Y.; Pelousse, F.; Bruyere, O. Safety concerns with the long-term management of osteoporosis. Expert Opin. Drug Saf. 2013, 12, 507-522. [CrossRef] [PubMed]

15. Hough, F.S.; Brown, S.L.; Cassim, B.; Davey, M.R.; de Lange, W.; de Villiers, T.J.; Ellis, G.C.; Lipschitz, S.; Lukhele, M.; Pettifor, J.M. The safety of osteoporosis medication. S. Afr. Med. J. 2014, 104, 279-282. [CrossRef] [PubMed]

16. Deal, C. Potential new drug targets for osteoporosis. Nat. Rev. Rheumatol. 2009, 5, 20. [CrossRef] [PubMed]

17. Kenakin, T.; Christopoulos, A. Signalling bias in new drug discovery: Detection, quantification and therapeutic impact. Nat. Rev. Drug Discov. 2013, 12, 205. [CrossRef] [PubMed]

18. Fouda, A.-M.; Youssef, A.R. Antiosteoporotic activity of salvadora persica sticks extract in an estrogen deficient model of osteoporosis. Osteoporos. Sarcopenia 2017, 3, 132-137. [CrossRef]

19. Zhang, N.-D.; Han, T.; Huang, B.-K.; Rahman, K.; Jiang, Y.-P.; Xu, H.-T.; Qin, L.-P.; Xin, H.-L.; Zhang, Q.-Y.; Li, Y.-M. Traditional chinese medicine formulas for the treatment of osteoporosis: Implication for antiosteoporotic drug discovery. J. Ethnopharmacol. 2016, 189, 61-80. [CrossRef] [PubMed]

20. Zhang, L.L.; Xu, W.; Xu, Y.L.; Chen, X.; Huang, M.; Lu, J.J. Therapeutic potential of rhizoma alismatis: A review on ethnomedicinal application, phytochemistry, pharmacology, and toxicology. Ann. N. Y. Acad. Sci. 2017, 1401, 90-101. [CrossRef] [PubMed]

21. Wang, L.; He, Y.J.; Han, T.; Zhao, L.; Lv, L.; He, Y.Q.; Zhang, Q.Y.; Xin, H.L. Metabolites of curculigoside in rats and their antiosteoporotic activities in osteoblastic mc3t3-e1 cells. Fitoterapia 2017, 117, 109-117. [CrossRef] [PubMed]

22. Desai, S.; Babaria, P.; Nakarani, M.; Shah, K.; Paranjape, A. Antiosteoporotic effect of hemidesmus indicus linn. On ovariectomised rats. J. Ethnopharmacol. 2017, 199, 1-8. [CrossRef] [PubMed]

23. Ahmad, N.; Chillara, R.; Kushwaha, P.; Khedgikar, V.; Karvande, A.; Choudhary, D.; Adhikary, S.; Maurya, R.; Trivedi, R. Evaluation of anti-osteoporotic activity of butanolic fraction from passiflora foetida in ovariectomy-induced bone loss in mice. Biomed. Pharmacother. 2017, 88, 804-813. [CrossRef] [PubMed]

24. Tasadduq, R.; Gordon, J.; Al-Ghanim, K.A.; Lian, J.B.; Van Wijnen, A.J.; Stein, J.L.; Stein, G.S.; Shakoori, A.R. Ethanol extract of cissus quadrangularis enhances osteoblast differentiation and mineralization of murine pre-osteoblastic mc3t3-e1 cells. J. Cell. Physiol. 2017, 232, 540-547. [CrossRef] [PubMed]

25. Karvande, A.; Khedgikar, V.; Kushwaha, P.; Ahmad, N.; Kothari, P.; Verma, A.; Kumar, P.; Nagar, G.K.; Mishra, P.R.; Maurya, R. Heartwood extract from dalbergia sissoo promotes fracture healing and its application in ovariectomy-induced osteoporotic rats. J. Pharm. Pharmacol. 2017, 69, 1381-1397. [CrossRef] [PubMed]

26. Jia, M.; Nie, Y.; Cao, D.-P.; Xue, Y.-Y.; Wang, J.-S.; Zhao, L.; Rahman, K.; Zhang, Q.-Y.; Qin, L.-P. Potential antiosteoporotic agents from plants: A comprehensive review. Evid.-Based Complement. Altern. Med. 2012, 2012, 364604. [CrossRef] [PubMed]

27. Liu, X.L.; Li, J.H.; Yang, Y.F.; Zhu, J.Y. Floral development of gymnospermium microrrhynchum (berberidaceae) and its systematic significance in the nandinoideae. Flora 2017, 228, 10-16. [CrossRef]

28. Sheng, M.; Chen, Q.; Wang, L.; Tian, X. Hybridization among epimedium (berberidaceae) species native to china. Sci. Hortic. 2011, 128, 342-351. [CrossRef]

29. Indran, I.R.; Liang, R.L.Z.; Min, T.E.; Yong, E.-L. Preclinical studies and clinical evaluation of compounds from the genus epimedium for osteoporosis and bone health. Pharmacol. Ther. 2016, 162, 188-205. [CrossRef] [PubMed]

30. Ma, H.; He, X.; Yang, Y.; Li, M.; Hao, D.; Jia, Z. The genus epimedium: An ethnopharmacological and phytochemical review. J. Ethnopharmacol. 2011, 134, 519-541. [CrossRef] [PubMed]

31. Hsieh, T.P.; Sheu, S.Y.; Sun, J.S.; Chen, M.H.; Liu, M.H. Icariin isolated from epimedium pubescens regulates osteoblasts anabolism through bmp-2, smad4, and cbfa1 expression. Phytomedicine 2010, 17, 414-423. [CrossRef] [PubMed]

32. Tantry, M.A.; Dar, J.A.; Idris, A.; Akbar, S.; Shawl, A.S. Acylated flavonol glycosides from epimedium elatum, a plant endemic to the western himalayas. Fitoterapia 2012, 83, 665-670. [CrossRef] [PubMed] 
33. Hidaka, S.; Okamoto, Y.; Miyazaki, K.; Uesugi, T. Evaluation of a soybean product fujiflavone p40 as an antiosteoporotic agent in rats. Phytother. Res. 2003, 17, 112-119. [CrossRef] [PubMed]

34. Ye, S.F.; Saga, I.; Ichimura, K.; Nagai, T.; Shinoda, M.; Matsuzaki, S. Coumestrol as well as isoflavones in soybean extract prevent bone resorption in ovariectomized rats. Endocr. Regul. 2003, 37, 145-152. [PubMed]

35. Chin, K.Y.; Ima-Nirwana, S. Can soy prevent male osteoporosis? A review of the current evidence. Curr. Drug Targets 2013, 14, 1632-1641. [CrossRef] [PubMed]

36. Lambert, M.N.T.; Thybo, C.B.; Lykkeboe, S.; Rasmussen, L.M.; Frette, X.; Christensen, L.P.; Jeppesen, P.B. Combined bioavailable isoflavones and probiotics improve bone status and estrogen metabolism in postmenopausal osteopenic women: A randomized controlled trial. Am. J. Clin. Nutr. 2017, 106, 909-920. [CrossRef] [PubMed]

37. Ricci, E.; Cipriani, S.; Chiaffarino, F.; Malvezzi, M.; Parazzini, F. Soy isoflavones and bone mineral density in perimenopausal and postmenopausal western women: A systematic review and meta-analysis of randomized controlled trials. J. Womens Health (Larchmt) 2010, 19, 1609-1617. [CrossRef] [PubMed]

38. Taku, K.; Melby, M.K.; Kurzer, M.S.; Mizuno, S.; Watanabe, S.; Ishimi, Y. Effects of soy isoflavone supplements on bone turnover markers in menopausal women: Systematic review and meta-analysis of randomized controlled trials. Bone 2010, 47, 413-423. [CrossRef] [PubMed]

39. Arcoraci, V.; Atteritano, M.; Squadrito, F.; D’Anna, R.; Marini, H.; Santoro, D.; Minutoli, L.; Messina, S.; Altavilla, D.; Bitto, A. Antiosteoporotic activity of genistein aglycone in postmenopausal women: Evidence from a post-hoc analysis of a multicenter randomized controlled trial. Nutrients 2017, 9, 179. [CrossRef] [PubMed]

40. Jin, X.; Sun, J.; Yu, B.; Wang, Y.; Sun, W.J.; Yang, J.; Huang, S.H.; Xie, W.L. Daidzein stimulates osteogenesis facilitating proliferation, differentiation, and antiapoptosis in human osteoblast-like mg-63 cells via estrogen receptor-dependent mek/erk and pi3k/akt activation. Nutr. Res. 2017, 42, 20-30. [CrossRef] [PubMed]

41. Zhai, Y.; Li, Y.; Wang, Y.; Cui, J.; Feng, K.; Kong, X.; Chen, L. Psoralidin, a prenylated coumestan, as a novel anti-osteoporosis candidate to enhance bone formation of osteoblasts and decrease bone resorption of osteoclasts. Eur. J. Pharmacol. 2017, 801, 62-71. [CrossRef] [PubMed]

42. Chopra, B.; Dhingra, A.K.; Dhar, K.L. Psoralea corylifolia 1. (buguchi)—Folklore to modern evidence: Review. Fitoterapia 2013, 90, 44-56. [CrossRef] [PubMed]

43. Weng, Z.-B.; Gao, Q.-Q.; Wang, F.; Zhao, G.-H.; Yin, F.-Z.; Cai, B.-C.; Chen, Z.-P.; Li, W.-D. Positive skeletal effect of two ingredients of Psoralea corylifolia L. On estrogen deficiency-induced osteoporosis and the possible mechanisms of action. Mol. Cell. Endocrinol. 2015, 417, 103-113. [CrossRef] [PubMed]

44. Tang, D.-Z.; Yang, F.; Yang, Z.; Huang, J.; Shi, Q.; Chen, D.; Wang, Y.-J. Psoralen stimulates osteoblast differentiation through activation of bmp signaling. Biochem. Biophys. Res. Commun. 2011, 405, $256-261$. [CrossRef] [PubMed]

45. Li, F.; Li, Q.; Huang, X.; Wang, Y.; Ge, C.; Qi, Y.; Guo, W.; Sun, H. Psoralen stimulates osteoblast proliferation through the activation of nuclear factor-kb-mitogen-activated protein kinase signaling. Exp. Ther. Med. 2017, 14, 2385-2391. [CrossRef] [PubMed]

46. Sen, C.K.; Rink, C.; Khanna, S.; Palm o Chen, R.; Zhang, Y.; Dong, L.; Huang, J.; Hua, S.; Fu, X. Current Persperctive in the Discovery of Anti-aging Agents from Natural Products. Int. J. Curr. Adv. Res. 2017, 27, 335-404.

47. Sen, C.K.; Rink, C.; Khanna, S. Palm oil-derived natural vitamin e $\alpha$-tocotrienol in brain health and disease. J. Am. Coll. Nutr. 2010, 29, 314S-323S. [CrossRef] [PubMed]

48. Sundram, K.; Sambanthamurthi, R.; Tan, Y.-A. Palm fruit chemistry and nutrition. Asia Pac. J. Clin. Nutr. 2003, 12, 355-362. [PubMed]

49. Reeves, J., III; Weihrauch, J.L. Composition of Foods. Fats and Oils, Raw-Processed-Prepared; Chigago, IL, USA, 1979. Available online: https:/ / www.cabdirect.org/cabdirect/abstract/19811420761 (accessed on 10 May 2018).

50. Mustapa, A.; Manan, Z.; Azizi, C.M.; Setianto, W.; Omar, A.M. Extraction of $\beta$-carotenes from palm oil mesocarp using sub-critical r134a. Food Chem. 2011, 125, 262-267. [CrossRef]

51. Poku, K. Small-Scale Palm Oil Processing in Africa; Food \& Agriculture Org.: Roma, Italy, 2002; Volume 148.

52. Peh, H.Y.; Tan, W.D.; Liao, W.; Wong, W.F. Vitamin e therapy beyond cancer: Tocopherol versus tocotrienol. Pharmacol. Ther. 2016, 162, 152-169. [CrossRef] [PubMed] 
53. Ahsan, H.; Ahad, A.; Iqbal, J.; Siddiqui, W.A. Pharmacological potential of tocotrienols: A review. Nutr. Metab. 2014, 11, 52. [CrossRef] [PubMed]

54. Zhao, L.; Fang, X.; Marshall, M.R.; Chung, S. Regulation of obesity and metabolic complications by gamma and delta tocotrienols. Molecules 2016, 21, 344. [CrossRef] [PubMed]

55. Shen, C.L.; Klein, A.; Chin, K.Y.; Mo, H.; Tsai, P.; Yang, R.S.; Chyu, M.C.; Ima-Nirwana, S. Tocotrienols for bone health: A translational approach. Ann. N. Y. Acad. Sci. 2017, 1401, 150-165. [CrossRef] [PubMed]

56. Ng, M.H.; Choo, Y.M.; Ma, A.N.; Chuah, C.H.; Hashim, M.A. Separation of vitamin e (tocopherol, tocotrienol, and tocomonoenol) in palm oil. Lipids 2004, 39, 1031-1035. [CrossRef] [PubMed]

57. Frega, N.; Mozzon, M.; Bocci, F. Identification and estimation of tocotrienols in the annatto lipid fraction by gas chromatography-mass spectrometry. J. Am. Oil Chem. Soc. 1998, 75, 1723-1727. [CrossRef]

58. Chin, K.-Y.; Ima-Nirwana, S. The biological effects of tocotrienol on bone: A review on evidence from rodent models. Drug Des. Dev. Ther. 2015, 9, 2049. [CrossRef] [PubMed]

59. Wong, S.K.; Chin, K.-Y.; Suhaimi, F.H.; Ahmad, F.; Ima-Nirwana, S. The effects of palm tocotrienol on metabolic syndrome and bone loss in male rats induced by high-carbohydrate high-fat diet. J. Funct. Foods 2018, 44, 246-254. [CrossRef]

60. Ginaldi, L.; Di Benedetto, M.C.; De Martinis, M. Osteoporosis, inflammation and ageing. Immun. Ageing 2005, 2, 14. [CrossRef] [PubMed]

61. Manolagas, S.C. From estrogen-centric to aging and oxidative stress: A revised perspective of the pathogenesis of osteoporosis. Endocr. Rev. 2010, 31, 266-300. [CrossRef] [PubMed]

62. Fatokun, A.A.; Stone, T.W.; Smith, R.A. Responses of differentiated mc3t3-e1 osteoblast-like cells to reactive oxygen species. Eur. J. Pharmacol. 2008, 587, 35-41. [CrossRef] [PubMed]

63. Ha, H.; Kwak, H.B.; Lee, S.W.; Jin, H.M.; Kim, H.-M.; Kim, H.-H.; Lee, Z.H. Reactive oxygen species mediate rank signaling in osteoclasts. Exp. Cell Res. 2004, 301, 119-127. [CrossRef] [PubMed]

64. McLean, R.R. Proinflammatory cytokines and osteoporosis. Curr. Osteoporos. Rep. 2009, 7, 134-139. [CrossRef] [PubMed]

65. Hermizi, H.; Faizah, O.; Ima-Nirwana, S.; Nazrun, S.A.; Norazlina, M. Beneficial effects of tocotrienol and tocopherol on bone histomorphometric parameters in sprague-dawley male rats after nicotine cessation. Calcif. Tissue Int. 2009, 84, 65-74. [CrossRef] [PubMed]

66. Aktifanus, A.T.; Shuid, A.N.; Rashid, N.H.A.; Ling, T.H.; Loong, C.Y.; Saat, N.M.; Muhammad, N.; Mohamed, N.; Soelaiman, I.N. Comparison of the effects of tocotrienol and estrogen on the bone markers and dynamic changes in postmenopausal osteoporosis rat model. Asian J. Anim. Vet. Adv. 2012, 7, 225-234.

67. Soelaiman, I.N.; Ming, W.; Abu Bakar, R.; Hashnan, N.A.; Mohd Ali, H.; Mohamed, N.; Muhammad, N.; Shuid, A.N. Palm tocotrienol supplementation enhanced bone formation in oestrogen-deficient rats. Int. J. Endocrinol. 2012, 2012, 532862. [CrossRef] [PubMed]

68. Norazlina, M.; Ima-Nirwana, S.; Gapor, M.; Khalid, B. Palm vitamin e is comparable to $\alpha$-tocopherol in maintaining bone mineral density in ovariectomised female rats. Exp. Clin. Endocrinol. Diabetes 2000, 108, 305-310. [CrossRef] [PubMed]

69. Ima-Nirwana, S.; Kiftiah, A.; Zainal, A.; Norazlina, M.; Gapor, M.; Khalid, B. Palm vitamin e prevents osteoporosis in orchidectomized growing male rats. Nat. Prod. Sci. 2000, 6, 155-160.

70. Ima, S.N.; Fakhrurazi, H. Palm vitamin eprotects bone against dexamethasone-induced osteoporosis in male rats. Med. J. Malaysia 2002, 57, 136-144.

71. Chin, K.-Y.; Gengatharan, D.; Mohd Nasru, F.S.; Khairussam, R.A.; Ern, S.L.H.; Aminuddin, S.A.W.; Ima-Nirwana, S. The effects of annatto tocotrienol on bone biomechanical strength and bone calcium content in an animal model of osteoporosis due to testosterone deficiency. Nutrients 2016, 8, 808. [CrossRef] [PubMed]

72. Mohamad, N.-V.; Ima-Nirwana, S.; Chin, K.-Y. Effect of tocotrienol from bixa orellana (annatto) on bone microstructure, calcium content, and biomechanical strength in a model of male osteoporosis induced by buserelin. Drug Des. Dev. Ther. 2018, 12, 555. [CrossRef] [PubMed]

73. Mohamad, N.V.; Soelaiman, I.N.; Chin, K.Y. Effects of tocotrienol from bixa orellana (annatto) on bone histomorphometry in a male osteoporosis model induced by buserelin. Biomed. Pharmacother. 2018, 103, 453-462. [CrossRef] [PubMed]

74. Chin, K.Y.; Ima-Nirwana, S. Effects of annatto-derived tocotrienol supplementation on osteoporosis induced by testosterone deficiency in rats. Clin. Interv. Aging 2014, 9, 1247-1259. [CrossRef] [PubMed] 
75. Chin, K.Y.; Ima-Nirwana, S. The effects of alpha-tocopherol on bone: A double-edged sword? Nutrients 2014, 6, 1424-1441. [CrossRef] [PubMed]

76. Guralp, O. Effects of vitamin e on bone remodeling in perimenopausal women: Mini review. Maturitas 2014, 79, 476-480. [CrossRef] [PubMed]

77. Shen, C.-L.; Yang, S.; Tomison, M.D.; Romero, A.W.; Felton, C.K.; Mo, H. Tocotrienol supplementation suppressed bone resorption and oxidative stress in postmenopausal osteopenic women: A 12-week randomized double-blinded placebo-controlled trial. Osteoporos. Int. 2018, 29, 881-891. [CrossRef] [PubMed]

78. Li, X.; Xu, X.; Wang, J.; Yu, H.; Wang, X.; Yang, H.; Xu, H.; Tang, S.; Li, Y.; Yang, L. A system-level investigation into the mechanisms of chinese traditional medicine: Compound danshen formula for cardiovascular disease treatment. PLoS ONE 2012, 7, e43918. [CrossRef] [PubMed]

79. Wu, W.-Y.; Wang, Y.-P. Pharmacological actions and therapeutic applications of salvia miltiorrhiza depside salt and its active components. Acta Pharmacol. Sin. 2012, 33, 1119. [CrossRef] [PubMed]

80. Guo, Y.; Li, Y.; Xue, L.; Severino, R.P.; Gao, S.; Niu, J.; Qin, L.-P.; Zhang, D.; Brömme, D. Salvia miltiorrhiza: An ancient chinese herbal medicine as a source for anti-osteoporotic drugs. J. Ethnopharmacol. 2014, 155, 1401-1416. [CrossRef] [PubMed]

81. Baricevic, D.; Bartol, T.V. Pharmacology 11. The biological/pharmacological activity of the salvia genus. In The Genus Salvia; Kintzios, S.E., Ed.; Harwood Academic Publishers: Amsterdam, The Netherland, 2000; pp. 143-184.

82. Kim, H.-K.; Woo, E.-R.; Lee, H.-W.; Park, H.-R.; Kim, H.-N.; Jung, Y.-K.; Choi, J.-Y.; Chae, S.-W.; Kim, H.-R.; Chae, H.-J. The correlation of salvia miltiorrhiza extract-induced regulation of osteoclastogenesis with the amount of components tanshinone i, tanshinone iia, cryptotanshinone, and dihydrotanshinone. Immunopharmacol. Immunotoxicol. 2008, 30, 347-364. [CrossRef] [PubMed]

83. Lee, S.-Y.; Choi, D.-Y.; Woo, E.-R. Inhibition of osteoclast differentiation by tanshinones from the root ofsalvia miltiorrhiza bunge. Arch. Pharm. Res. 2005, 28, 909-913. [CrossRef] [PubMed]

84. Kwak, H.B.; Yang, D.; Ha, H.; Lee, J.-H.; Kim, H.-N.; Woo, E.-R.; Lee, S.; Kim, H.-H.; Lee, Z.H. Tanshinone iia inhibits osteoclast differentiation through down-regulation of c-fos and nfatc1. Exp. Mol. Med. 2006, 38, 256. [CrossRef] [PubMed]

85. Cui, L.; Liu, Y.-Y.; Wu, T.; Ai, C.-M.; Chen, H.-Q. Osteogenic effects of d (+) $\beta$-3, 4-dihydroxyphenyl lactic acid (salvianic acid a, saa) on osteoblasts and bone marrow stromal cells of intact and prednisone-treated rats. Acta Pharmacol. Sin. 2009, 30, 321. [CrossRef] [PubMed]

86. Cui, L.; Li, T.; Liu, Y.; Zhou, L.; Li, P.; Xu, B.; Huang, L.; Chen, Y.; Liu, Y.; Tian, X. Salvianolic acid b prevents bone loss in prednisone-treated rats through stimulation of osteogenesis and bone marrow angiogenesis. PLOS ONE 2012, 7, e34647. [CrossRef] [PubMed]

87. Thu, H.E.; Mohamed, I.N.; Hussain, Z.; Jayusman, P.A.; Shuid, A.N. Eurycoma longifolia as a potential adoptogen of male sexual health: A systematic review on clinical studies. Chin. J. Nat. Med. 2017, 15, 71-80. [CrossRef]

88. Edwards, S.E.; da Costa Rocha, I.; Williamson, E.M.; Heinrich, M. Tongkat ali eurycoma longifolia jack. In Phytopharmacy: An Evidence-Based Guide to Herbal Medicinal Products; John Wiley \& Sons: Hoboken, NJ, USA, 2015; p. 375.

89. Faisal, G.G.; Zakaria, S.M.; Najmuldeen, G.F.; Al-Ani, I.M. Antifungal activity of eurycoma longifolia jack (tongkat ali) root extract. J. Int. Dent. Med. Res. 2016, 9, 70-74.

90. Thu, H.E.; Mohamed, I.N.; Hussain, Z.; Shuid, A.N. Eurycoma longifolia as a potential alternative to testosterone for the treatment of osteoporosis: Exploring time-mannered proliferative, differentiative and morphogenic modulation in osteoblasts. J. Ethnopharmacol. 2017, 195, 143-158. [CrossRef] [PubMed]

91. Low, B.-S.; Choi, S.-B.; Abdul Wahab, H.; Kumar Das, P.; Chan, K.-L. Eurycomanone, the major quassinoid in eurycoma longifolia root extract increases spermatogenesis by inhibiting the activity of phosphodiesterase and aromatase in steroidogenesis. J. Ethnopharmacol. 2013, 149, 201-207. [CrossRef] [PubMed]

92. Chin, K.-Y.; Ima-Nirwana, S. Sex steroids and bone health status in men. Int. J. Endocrinol. 2012, $2012,7$. [CrossRef] [PubMed]

93. Mohamad, N.-V.; Soelaiman, I.-N.; Chin, K.-Y. A concise review of testosterone and bone health. Clin. Interv. Aging 2016, 11, 1317. [CrossRef] [PubMed] 
94. Huber, D.M.; Bendixen, A.C.; Pathrose, P.; Srivastava, S.; Dienger, K.M.; Shevde, N.K.; Pike, J.W. Androgens suppress osteoclast formation induced by rankl and macrophage-colony stimulating factor. Endocrinology 2001, 142, 3800-3808. [CrossRef] [PubMed]

95. Chin, K.Y.; Ima-Nirwana, S. The effects of orchidectomy and supraphysiological testosterone administration on trabecular bone structure and gene expression in rats. Aging Male 2015, 18, 60-66. [CrossRef] [PubMed]

96. Corona, G.; Sforza, A.; Maggi, M. Testosterone replacement therapy: Long-term safety and efficacy. World J. Men's Health 2017, 35, 65-76. [CrossRef] [PubMed]

97. Shuid, A.N.; Ping, L.L.; Muhammad, N.; Mohamed, N.; Soelaiman, I.N. The effects of Labisia pumila var. Alata on bone markers and bone calcium in a rat model of post-menopausal osteoporosis. J. Ethnopharmacol. 2011, 133, 538-542. [CrossRef] [PubMed]

98. Fathilah, S.N.; Nazrun Shuid, A.; Mohamed, N.; Muhammad, N.; Nirwana Soelaiman, I. Labisia pumila protects the bone of estrogen-deficient rat model: A histomorphometric study. J. Ethnopharmacol. 2012, 142, 294-299. [CrossRef] [PubMed]

99. Nadia, M.; Nazrun, A.; Norazlina, M.; Isa, N.; Norliza, M.; Ima Nirwana, S. The anti-inflammatory, phytoestrogenic, and antioxidative role of Labisia pumila in prevention of postmenopausal osteoporosis. Adv. Pharmacol. Sci. 2012, 2012, 706905. [PubMed]

100. Mohd Effendy, N.; Abdullah, S.; Yunoh, M.F.; Shuid, A.N. Time and dose-dependent effects of Labisia pumila on the bone strength of postmenopausal osteoporosis rat model. BMC Complement. Altern. Med. 2015, 15, 58. [CrossRef] [PubMed]

101. Fathilah, S.N.; Mohamed, N.; Muhammad, N.; Mohamed, I.N.; Soelaiman, I.N.; Shuid, A.N. Labisia pumila regulates bone-related genes expressions in postmenopausal osteoporosis model. BMC Complement. Altern. Med. 2013, 13, 217. [CrossRef] [PubMed]

102. Effendy, N.M.; Shuid, A.N. Time and dose-dependent effects of Labisia pumila on bone oxidative status of postmenopausal osteoporosis rat model. Nutrients 2014, 6, 3288-3302. [CrossRef] [PubMed]

(C) 2018 by the authors. Licensee MDPI, Basel, Switzerland. This article is an open access article distributed under the terms and conditions of the Creative Commons Attribution (CC BY) license (http:/ / creativecommons.org/licenses/by/4.0/). 